\title{
Association between the vitamin D receptor gene polymorphism and osteoporosis
}

\author{
JU WU*, DE-PENG SHANG ${ }^{*}$, SHENG YANG, DA-PENG FU, \\ HAO-YI LING, SHUANG-SHUANG HOU and JIAN-MIN LU
}

Department of Orthopaedics, Affiliated Zhongshan Hospital of Dalian University, Dalian, Liaoning 116001, P.R. China

Received December 15, 2015; Accepted March 2, 2016

DOI: $10.3892 /$ br.2016.697

\begin{abstract}
The influence of the vitamin D receptor (VDR) gene for the risk of osteoporosis remains to be elucidated. The aim of the present study was to understand the distribution of various single-nucleotide polymorphisms (SNPs) within the $V D R$ gene and its association with the risk of osteoporosis. In total, 378 subjects without a genetic relationship were recruited to the study between January 2013 and July 2015. The subjects were divided into three groups, which were the normal $(n=234)$, osteoporosis $(n=65)$ and osteoporosis with osteoporotic fracture ( $\mathrm{n}=79)$ groups. Three pertinent SNPs of the VDR gene rs17879735 (ApaI, Allele A/a, SNP C $>$ A) were examined with polymerase chain reaction-restriction fragment length polymorphism. The bone mineral density (BMD) of the lumbar spine (L2-L4), femoral neck, Ward's and Tro was measured using dual-energy $\mathrm{X}$-ray absorptiometry. The distributions of genotype frequencies aa, AA and Aa were 48.68, 42.86 and 8.46\%, separately. Following analysis of each site, BMD, body mass index (BMI) and age, BMD for each site was negatively correlated with age $(\mathrm{P}<0.01)$ and positively correlated with $\mathrm{BMI}(\mathrm{P}<0.01)$. Correction analysis revealed that there were significant differences in the Ward's triangle BMD among each genotype $(\mathrm{P}<0.05)$, in which the aa genotype exhibited the lower BMD $(\mathrm{P}<0.05)$. No significant difference was identified among the different genotypes in the occurrence of osteoporosis with osteoporotic fracture ( $\mathrm{P}>0.05)$. In conclusion, these indicated that the VDR gene ApaI polymorphisms had an important role in the osteoporosis risk.
\end{abstract}

\section{Introduction}

Osteoporosis is a multifactorial skeletal disease characterized by a reduced bone mineral density (BMD) and increased

Correspondence to: Dr Jian-Min Lu, Department of Orthopaedics, Affiliated Zhongshan Hospital of Dalian University, 6 Jiefang Street, Dalian, Liaoning 116001, P.R. China

E-mail: lujianmin_11@163.com

${ }^{*}$ Contributed equally

Key words: vitamin D receptor, polymorphism, osteoporosis, bone mineral density fracture risk, which is an increasing health problem (1). In certain studies, environmental, twin and family studies have shown that BMD and bone turnover are under strong genetic control $(2,3)$. Genetic revelations have started elucidating the complex associations of vitamin D signaling and bone health (4-6). The vitamin D endocrine system has a role in the intestinal absorption of calcium and phosphate. This action of vitamin $\mathrm{D}$ is mediated through vitamin $\mathrm{D}$ receptor $(V D R)$ that specifically binds to 1,25-dihydroxyvitamin D3 for the regulation of skeletal development, maintenance of skeletal architecture, hormone secretion and immune function (7). The gene encoding for $V D R$ is considered as a candidate for genetic regulation of bone strength and metabolism. It is localized on chromosome 12 cen-q12, has 11 exons and spans $\sim 75 \mathrm{~kb}$ of genomic DNA $(8,9)$.

Morrison et al (10) reported a strong association between a $V D R$ gene $B s m I$ polymorphism and lumbar and femoral neck (FN) BMDs. Several studies have examined genetic polymorphisms within the $V D R$ gene, such as $B s m \mathrm{I}$ [allele $\mathrm{B} / \mathrm{b}$, single-nucleotide polymorphism (SNP) G>A, rs1544410], ApaI (allele A/a, SNP C>A, rs17879735) and TaqI (allele T/t, SNP T>C, rs731236), for their influence on BMD and fracture risk (10-13). Current meta-analyses appear to be suggestive rather than conclusive, as certain studies have shown a significant association of the VDR gene polymorphism with BMD (14-17), whereas others report contrarily (18-21). These inconsistencies are addressing that the genetic risk involved in osteoporosis may be attributable to genetic heterogeneity, population admixture, gene-environments and gene-gene interactions.

Associations between the $V D R$ gene polymorphism and osteoporosis and BMD are affected by ethnicities of the subjects, live environments and the standard and size of the samples. China has a large area and population, as well as various life styles. Therefore, the present study was carried out to examine the influence of rs17879735 within the VDR gene on BMD and their coordinated effects as the genetic mediators of osteoporosis in the Chinese population.

\section{Materials and methods}

Subjects. The case controls were recruited from the Department of Endocrinology and Metabolism, and the Department of Osteoporosis in Zhongshan Hospital Affiliated of Dalian University (Dalian, Liaoning, China). The local ethic committee 
Table I. Genotype and allele frequencies of vitamin D receptor.

\begin{tabular}{lrrrrrrr}
\hline & \multicolumn{3}{c}{ Genotype, } & & \multicolumn{2}{c}{ Allele, $\mathrm{n}$} \\
\cline { 2 - 3 } Gender (n) & aa & AA & aa & & a & A \\
\hline Male (101) & 47 & 44 & 10 & & 138 & 64 \\
Female (277) & 137 & 118 & 22 & & 392 & 162 \\
Total (378) & 184 & 162 & 32 & & 530 & 226 \\
\hline
\end{tabular}

Table II. Correlation analysis of bone mineral density among patients with different BMIs, ages and body sections.

\begin{tabular}{lrrrrr}
\hline & \multicolumn{2}{c}{ Age } & & \multicolumn{2}{c}{ BMI } \\
\cline { 2 - 3 } \cline { 6 - 7 } Section & \multicolumn{1}{c}{$\mathrm{r}$} & P-value & & $\mathrm{r}$ & P-value \\
\hline Lumbar vertebrae & -0.316 & $<0.001$ & & 0.272 & 0.000 \\
Femoral neck & -0.349 & $<0.001$ & & 0.174 & 0.004 \\
Ward's triangle & -0.165 & 0.003 & & 0.183 & 0.002 \\
Great trochanter & -0.231 & $<0.001$ & & 0.191 & 0.001 \\
\hline
\end{tabular}

BMI, body mass index.

Table III. Correlation between the vitamin D receptor genotype and bone mineral density of different body sections subsequent to correcting the age and body mass index.

\begin{tabular}{llccc}
\hline & \multicolumn{3}{c}{ ApaI genotype } \\
\cline { 2 - 4 } Site & AA & Aa & aa & P-value \\
\hline L2-4 & $1.082^{\mathrm{a}}$ & $0.995^{\mathrm{a}}$ & 0.869 & 0.032 \\
FN & 0.893 & 0.867 & 0.762 & 0.138 \\
Wards & $0.697^{\mathrm{a}}$ & 0.754 & 0.524 & 0.047 \\
Tro & 0.741 & 0.711 & 0.687 & 0.221 \\
\hline
\end{tabular}

${ }^{\mathrm{a}} \mathrm{P}<0.05$, compared with ApaI aa genotype.

approved the study, and participants signed informed consent prior to giving their blood sample. Patients were excluded if they had diseases capable of influencing calcium and phosphorus metabolism, such as hyperparathyroidism, renal failure, liver diseases, hyperthyroidism, hypocortisolism, diabetes and other chronic illnesses. A total of 378 subjects (normal BMD, 234 cases; and decreasing BMD, 65 cases) and 79 patients with osteoporosis with osteoporotic fracture were recruited and they were divided into three groups, which were the normal, osteoporosis and osteoporosis with osteoporotic fracture groups. The subjects were aged between 49-84 years old, which included 101 males and 277 females. BMD of the lumbar spine (L2-L4), FN, Ward's and Tro was measured using dual-energy X-ray absorptiometry (Norland Medical Systems, White Plains, NY, USA). Osteoporosis was defined according to the 1994 classification of the WHO (22).
Genotyping. Blood samples were obtained from all the subjects in the morning, after an overnight fast. Venous blood $(5 \mathrm{ml})$ was withdrawn from the vein into Vacutainer tubes containing EDTA as the anticoagulant. Blood samples were centrifuged at 3,000 rpm for $10 \mathrm{~min}$. The buffy coat and red blood cell pellet were used for DNA extraction using the total blood DNA extraction kit (Tiagen Biotechnology Co., Ltd., Beijing, China). Genomic DNA was amplified by polymerase chain reaction (PCR) using VDR (rs17879735) specific primers (forward, 5'-CAGAGCATGGACAGGGAGCAA-3' and reverse, 5'-GCAACTCCTCATGGCTGAGGTCTC-3'). The program for the VDR PCR assay was as follows: Initial denaturation at $94^{\circ} \mathrm{C}$ for $3 \mathrm{~min}$, cycle denaturation at $94^{\circ} \mathrm{C}$ for $1 \mathrm{~min}$, cycle annealing at $66^{\circ} \mathrm{C}$ for $1 \mathrm{~min}$, cycle extension at $72^{\circ} \mathrm{C}$ for $1 \mathrm{~min}$, and final extension at $72^{\circ} \mathrm{C}$ for $7 \mathrm{~min}$. There were 40 cycles, and the assay was maintained at $8^{\circ} \mathrm{C}$ until the PCR product was removed. Subsequent to PCR, the products were digested with the restriction enzyme ApaI to ascertain the VDR gene polymorphism. The resulting fragments were subjected to electrophoresis, analyzed on $1.5 \%$ agarose gels and visualized with ethidium bromide.

Bone measurements. The measurements in grams per square centimeter were made of the BMDs of the lumbar spine (L2-4), FN, Ward's and Tro with Hologic densitometers (Hologic Inc., Waltham, MA, USA). Bone density scans used in the current analysis were those obtained at cohort baseline, when all women were designated as premenopausal or in early perimenopause on the basis of self-reported menstrual bleeding pattern variation. The cohort baseline BMD values were considered to approximate peak bone mass.

Statistical analysis. All SNP data were evaluated for Hardy-Weinberg equilibrium. Data were analyzed using the $\chi^{2}$ test and Fisher's exact test where appropriate. Analysis of covariance analysis was used to quantify the associations between lumbar spine-BMD and each of the VDR genotypes. All the significant tests were two-sided. Statistical analysis was performed using SPSS version 20.0 software (IBM, Corp., Armonk, NY, USA). For results where $\mathrm{P}<0.05$, exact $\mathrm{P}$-values are given. $\mathrm{P}<0.05$ was considered to indicate a statistically significant difference.

\section{Results}

Genotype distributions of VDR. The frequencies distribution of genotype and allele are shown in Table I. By analysis of the 378 subjects, the genotype frequencies were as follows: 48.68\% aa, $42.86 \%$ AA and $8.46 \%$ Aa.

Association between the VDR genotype and BMD of different sections of the body. Following analysis of each site, BMD, body mass index (BMI) and age, the BMD for each site was negatively correlated with age $(\mathrm{P}<0.01)$ and positively correlated with BMI $(\mathrm{P}<0.01)$, which suggested that age and BMI influenced the different site BMD (Table II). Correction analysis revealed that there were significant differences in the Ward's triangle BMD among each genotype $(\mathrm{P}<0.05)$, in which the aa genotype had the lowest BMD $(\mathrm{P}<0.05)$ (Table III). 
Table IV. Genotype frequencies in the osteoporotic fracture and normal groups.

\begin{tabular}{lcccr}
\hline & \multicolumn{3}{c}{ Genotype } & \\
\cline { 2 - 4 } Site & AA & Aa & aa & Total, n \\
\hline $\begin{array}{l}\text { Osteoporotic, } \\
\text { n (\%) }\end{array}$ & $43(54.43)$ & $9(11.39)$ & $27(34.18)$ & 79 \\
$\begin{array}{l}\text { Normal, } \\
\text { osteoporotic, } \\
\text { n } \%)\end{array}$ & $105(44.87)$ & $18(7.69)$ & $111(47.44)$ & 234 \\
\begin{tabular}{l} 
Total, n \\
\hline
\end{tabular} & 148 & 27 & 138 & 313 \\
\hline
\end{tabular}

$\chi^{2}=4.433, \mathrm{P}=0.109$.

Genotype frequencies in the osteoporotic fracture and normal groups. No significant difference was identified among the different genotypes in the occurrence of osteoporosis with osteoporotic fracture $(\mathrm{P}>0.05)$ (Table IV).

\section{Discussion}

Osteoporosis sickness (osteoporotic, OP) is suffering from injury to the bone tissue microstructure, the bone ingredient and the bone. The proportion continuously reduces, the bone qualitative change is thin, the bone brittleness increases and easy bone fracture is one type of whole body metabolism barrier disease (23). At present, the incidence of OP is continuously increasing and has the trend of rejuvenation. OP complicated various fractures seriously influenced people life quality. The relative gene polymorphisms were not only the important disease factors of OP (24), but are also beneficial to the early screening and prevention, as well as early diagnosis of molecular genetics (25). Various candidate genes polymorphisms may have an association with BMD, such as vitamin D, the estrogen receptor $(E R)$ gene, interleukin- 6 and transforming growth factor (26-29).

Presently, the $E R$ and $V D R$ genes have received the most attention, in which $V D R$ may be the main regulation gene (30). The human $V D R$ gene is located in chromosome 12 , with 44,000 bases and consists of 9 exons. Previous studies have examined genetic polymorphisms within the VDR gene, such as FokI (allele F/f, SNP C>T, rs2228570), BsmI (allele B/b, SNP G>A, rs1544410), ApaI (allele A/a, SNP C >A, rs17879735), and TaqI (allele T/t, SNP T>C, rs731236) for their influence on BMD and fracture risk. A number of domestic studies have reported the association between the VDR gene polymorphisms and BMD, and there were significant differences in results among countries, which also had mutual conflicts with each other.

The Australian study by Bell et al (30) reported that the ApaI genotype exhibited an association with lumbar BMD in two ethnicities, in which male lumbar BMD was lower in males with the aa compared to the AA genotype by $6.7 \%$. Dundar et al (31) reported that the lumbar BMD was lower in patients with the aa compared to the AA genotype in 136 cases of menopausal women. Additionally, Korean (32) and Spanish studies also revealed that the $V D R$ gene ApaI gene polymorphisms had an association with BMD in menopausal women (33). However, no effect was identified for the association of ApaI with BMD in the Chilean (34) and Finnish (35) studies. The study by Huang et al (36) suggested that the ApaI genotype had an association with the BMD of L1-4M, FN and Ward's triangle, as well as the BMC value, while no association with the BMD of Trochanter sites and BMC value was identified, which suggested that $A p a \mathrm{I}$ polymorphisms may influence the bone loss of cancellous bone and cortical bone in older males. Zhao et al (37) suggested that lumbar BMD was significantly lower in Han menopausal women with aa compared to the Aa genotype, while Lau et al (38) identified no association between the ApaI genotypes and BMD.

The genotype frequencies of the VDR gene were $48.68 \%$ aa, $42.86 \% \mathrm{AA}$ and $8.46 \% \mathrm{Aa}$, similar to its distribution in the Shanghai province, however, these were significantly different from Italian and Greek populations. The BMDs of the different sites were higher in the AA compared to the Aa and aa genotypes, and these were significantly negatively correlated with the age and significantly positively correlated with BMI. Following correction of age and BMI, significant differences were identified between lumbar and Ward's triangle BMD and different genotypes, which were in agreement with the Korean and Shanghai studies. These indicated that the VDR gene ApaI polymorphisms had an important role in the osteoporosis risk in the Chinese Han population.

The study of the association between the VDR gene polymorphisms and BMD found that patients with certain genotypes had low BMD, and their BMD significantly decreased with the aa genotype, which provided a theoretical basis for gene diagnosis and treatment for the Chinese Han population. In addition, subjects with a high risk of osteoporosis could be treated and prevented earlier.

Certain potential limitations of the present study may have influenced the results, such as the participants in the present study were Chinese Asians; and hence, the inferences may not be generalized to other populations. Furthermore, functional SNPs within the promoter region of $V D R$ gene that may influence the transcriptional efficacy are not taken into account, which may either mask or augment the expression of this genotype. Further studies of other SNPs with regard to osteoporosis using additional genetic markers may provide new information on the genetic background underlying osteoporosis in China.

\section{References}

1. Kelly PJ, Morrison NA, Sambrook PN, Nguyen TV and Eisman JA: Genetic influences on bone turnover, bone density and fracture. Eur J Endocrinol 133: 265-271, 1995.

2. Pocock NA, Eisman JA, Hopper JL, Yeates MG, Sambrook PN and Eberl S: Genetic determinants of bone mass in adults. A twin study. J Clin Invest 80: 706-710, 1987.

3. Guéguen R, Jouanny P, Guillemin F, Kuntz C, Pourel J and Siest G: Segregation analysis and variance components analysis of bone mineral density in healthy families. J Bone Miner Res 10: 2017-2022, 1995.

4. Yoshida T and Stern PH: How vitamin D works on bone. Endocrinol Metab Clin North Am 41: 557-569, 2012.

5. Carlberg C and Molnar F: Current status of vitamin D signaling and its therapeutic applications. Curr Top Med Chem 12: 528-547, 2012.

6. Turner AG, Anderson PH and Morris HA: Vitamin D and bone health. Scand J Clin Lab Invest Suppl 243: 65-72, 2012. 
7. Bouillon R, Okamura WH and Norman AW: Structure-function relationships in the vitamin D endocrine system. Endocr Rev 16: 200-257, 1995.

8. Miyamoto K, Kesterson RA, Yamamoto H, Taketani Y, Nishiwaki E, Tatsumi S, Inoue Y, Morita K, Takeda E and Pike JW: Structural organization of the human vitamin D receptor chromosomal gene and its promoter. Mol Endocrinol 11: 1165-1179, 1997

9. Taymans SE, Pack S, Pak E, Orban Z, Barsony J, Zhuang Z and Stratakis CA: The human vitamin D receptor gene (VDR) is localized to region 12 cen-q12 by fluorescent in situ hybridization and radiation hybrid mapping: Genetic and physical VDR map. J Bone Miner Res 14: 1163-1166, 1999.

10. Morrison NA, Qi JC, Tokita A, Kelly PJ, Crofts L, Nguyen TV, Sambrook PN and Eisman JA: Prediction of bone density from vitamin D receptor alleles. Nature 367: 284-287, 1994.

11. Sainz J, Van Tornout JM, Loro ML, Sayre J, Roe TF and Gilsanz V: Vitamin D-receptor gene polymorphisms and bone density in prepubertal American girls of Mexican descent N Engl J Med 337: 77-82, 1997.

12. Kurabayashi T, Tomita M, Matsushita H, Yahata T, Honda A, Takakuwa $\mathrm{K}$ and Tanaka K: Association of vitamin D and estrogen receptor gene polymorphism with the effect of hormone replacement therapy on bone mineral density in Japanese women. Am J Obstet Gynecol 180: 1115-1120, 1999.

13. Mencej-Bedrac S, Prezelj J, Kocjan T, Teskac K, Ostanek B, Smelcer M and Marc J: The combinations of polymorphisms in vitamin $\mathrm{D}$ receptor, osteoprotegerin and tumour necrosis factor superfamily member 11 genes are associated with bone mineral density. J Mol Endocrinol 42: 239-247, 2009.

14. Gong G, Stern HS, Cheng SC, Fong N, Mordeson J, Deng HW and Recker RR: The association of bone mineral density with vitamin D receptor gene polymorphisms. Osteoporos Int 9: 55-64, 1999.

15. Thakkinstian A, D'Este C, Eisman J, Nguyen T and Attia J: Meta-analysis of molecular association studies: Vitamin D receptor gene polymorphisms and BMD as a case study. J Bone Miner Res 19: 419-428, 2004.

16. Thakkinstian A, D'Este C and Attia J: Haplotype analysis of VDR gene polymorphisms: A meta-analysis. Osteoporos Int 15: 729-734, 2004.

17. Li Y, Xi B, Li K and Wang C: Association between vitamin D receptor gene polymorphisms and bone mineral density in Chinese women. Mol Biol Rep 39: 5709-5717, 2012.

18. Fang Y, Rivadeneira F, van Meurs JB, Pols HA, Ioannidis JP and Uitterlinden AG: Vitamin D receptor gene BsmI and TaqI polymorphisms and fracture risk: A meta-analysis. Bone 39 938-945, 2006

19. Uitterlinden AG, Ralston SH, Brandi ML, Carey AH, Grinberg D, Langdahl BL, Lips P, Lorenc R, Obermayer-Pietsch B, Reeve J, et al; APOSS Investigators; EPOS Investigators; EPOLOS Investigators; FAMOS Investigators; LASA Investigators; Rotterdam Study Investigators; GENOMOS Study: The association between common vitamin D receptor gene variations and osteoporosis: a participant-level meta-analysis. Ann Intern Med 145: 255-264, 2006.

20. Zintzaras E, Rodopoulou P and Koukoulis GN: BsmI, TaqI, ApaI and FokI polymorphisms in the vitamin D receptor (VDR) gene and the risk of osteoporosis: a meta-analysis. Dis Markers 22: 317-326, 2006

21. Qin G, Dong Z, Zeng P, Liu M and Liao X: Association of vitamin D receptor BsmI gene polymorphism with risk of osteoporosis: A meta-analysis of 41 studies. Mol Biol Rep 40: 497-506, 2013.
22. WHO Europe: A Declaration on the Promotion of Patients' Rights in Europe. European Journal of Health Law 1: 279-291, 1994.

23. Liu CL, Wu Y and Bi LF: Progress in osteoporosis-related gene research. Zhongguoguzhishusongzazhi 8: 731-735, 2011.

24. Bustamante M, Nogués X, Enjuanes A, Elosua R, García-Giralt N, Pérez-Edo L, Cáceres E, Carreras R, Mellibovsky L, Balcells S, et al: COL1A1, ESR1, VDR and TGFB1 polymorphisms and haplotypes in relation to BMD in Spanish postmenopausal women. Osteoporos Int 18: 235-243, 2007.

25. Wu D: The application of molecular genetics in osteoporosis diagnosis. Chinese Journal of Osteoporosis 5: 440-452, 2011.

26. Lu HJ, Li HL, Hao P, Li JM and Zhou LF: Association of the vitamin $\mathrm{D}$ receptor gene start codon polymorphism with vitamin D deficiency rickets. Zhonghua Er Ke Za Zhi 41: 493-496, 2003 (In Chinese).

27. He JW, Huang QR, Zhang ZL, Qin YJ, Lu JH, Li M, Zhou Q, $\mathrm{Hu}$ YQ, Liu YJ and Zhang H: Association of polymorphisms of estrogen receptor- $\alpha$ and vitamin D receptor genes with peak bone mass in Shanghai women. Chinese Journal of Endocrinology and Metabolism 20: 140-142, 2004.

28. Ye W, Peng Y, Huang DS, Liu SL, Ma NF, et al: Association of the promoter $-509 \mathrm{C}>\mathrm{T}$ polymorphism of transforming growth factor- $\beta 1$ with lumbar disc disease. Orthopedic Journal of China 14: 531-534, 2006.

29. Lei SF, Wu Y and Deng HW: Study progress of association of the vitamin D receptor $\alpha$ gene with OP. zhonghualaonianyixuezazhi 24: 473-475,2005.

30. Bell NH, Morrison NA, Nguyen TV, Eisman J and Hollis BW: ApaI polymorphisms of the vitamin D receptor predict bone density of the lumbar spine and not racial difference in bone density in young men. J Lab Clin Med 137: 133-140, 2001.

31. Dundar U, Solak M, Kavuncu V, Ozdemir M, Cakir T, Yildiz H and Evcik D: Evidence of association of vitamin D receptor Apa I gene polymorphism with bone mineral density in postmenopausal women with osteoporosis. Clin Rheumatol 28: 1187-1191, 2009.

32. Choi YM, Jun JK, Choe J, Hwang D, Park SH, Ku SY, Kang D, Kim JG, Moon SY and Lee JY: Association of the vitamin D receptor start codon polymorphism (FokI) with bone mineral density in postmenopausal Korean women. J Hum Genet 45: 280-283, 2000

33. Zambrano-Morales M, Borjas L, Fernández E, Zabala W, de Romero P, Pineda L and Morales-Machín A: Association of the vitamin D receptor gene BBAAtt haplotype with osteoporosis in post-menopausic women. Invest Clin 49: 29-38, 2008 (In Spanish)

34. Quevedo LI, Martínez BM, Castillo NM and Rivera FN: Vitamin D receptor gene polymorphisms and risk of hip fracture in Chilean elderly women. Rev Med Chil 136: 475-481, 2008 (In Spanish).

35. Boschitsch E, Suk EK, Mayr WR, Lang T, Schwartz WM and Panzer S: Genotypes of the vitamin-D-receptor gene and bone mineral density in Caucasoid postmenopausal females. Maturitas 24: 91-96, 1996.

36. Huang QR, Zhang ZL, Qin YJ, He JW, Lu JH, et al: Association of vitamin D receptor Apa polymorphism with BMD of man. Acta Acad Med Sinicae 25: 254-257, 2003.

37. Zhao J, Zhou X, Meng X, Liu G, Xing X, Liu H and Xu L: Polymorphisms of vitamin $\mathrm{D}$ receptor gene and its association with bone mineral density and osteocalcin in Chinese. Chin Med J (Engl) 110: 366-371, 1997.

38. Lau EM, Lam V, Li M, Ho K and Woo J: Vitamin D receptor start codon polymorphism (Fok I) and bone mineral density in Chinese men and women. Osteoporos Int 13: 218-221, 2002. 